\section{Dispersal of Coffee Rust Hemileia vastatrix B. et Br.}

RAYNER ${ }^{1}$ has recently stated that uredospores of Hemileia vastatrix can be dislodged from pustules by sudden mechanical shock. In this he is in agreement with Nutman, Roberts, and Bock ${ }^{2}$, and with Bock $^{3}$.

The question is not, however, whether spores can be shaken into the air, but of their subsoquent fate. Can such spores causo infection at a distance or not ? In other words, is $H$. vastatrix air-borne as are the cereal rusts, or is it distributed over short distances only, by water-splash? Moreovor, which of these methods of dispersal is effective in building up seasonal epiphytotics? Rayner ${ }^{4-6}$ has supported the former viow, and in particular has suggested that the winds of the south-west monsoon carried the diseaso from Africa (its country of origin) to Asia. Bock ${ }^{8}$, on the othor hand, using the rotating-rod spore traps of Harrington, Gill and Warr ${ }^{7}$, has shown that under field conditions, at wind-speeds of up to $4.9 \mathrm{~m} . \mathrm{p} . \mathrm{h}$. inside the plantation, spores dislodged by mechanical shock do not rise above the level of the pustules from which they are detached, but fall rapidly to the ground. The data published by Burdekin ${ }^{8}$ support Bock's conclusions.

A characteristic of the ajr-borne rusts, as has been pointed out by Gaumann", is that a single spore can cause infection. We have transferred nearly 2,000 counted groups of uredospores of $H$. vastatrix to droplets of water on leaf-disks. Of a total of nearly one thousand 1-spore and 2-spore transfers less than 0.2 per cent resulted in infections, and even with the 10-spore and 20-spore groups only $1 \cdot 1$ per cont of infections were recorded. Groups of 150 spores, however, gave more than 90 per cent of infections. These results are in agreement with those of Bock ${ }^{3}$, who, using different techniques, demonstrated that an average concentration of spores on the leaf surface of 15-30 spores per $\mathrm{cm} .^{2}$ is necessary for infection.

Bock $^{3}$ has also shown, on the basis of $450-\mathrm{hr}$ trapping in a heavily infected plantation, that if all the spores which became air-borne during a $24 \mathrm{hr}$. period were concentrated on the lower surfaces of the leaves, this would represent an average of only $0 \cdot 12$ spores per cm. ${ }^{2}$, too low a number to cause infection. On the other hand, a single shower of 0.8 in. resulted in a concentration of 25 spores per cm. ${ }^{2}$. He also found that a linear relationship held between the number of spores dispersed on the lower surfaces of leaves, and the amount of rainfall (in excess of $0.3 \mathrm{in}$.) causing the dispersal.

Rayner ${ }^{1}$ has stated that the lesions, becauso they are confined to the lower surfaces of leaves, would be too infrequently hit by water-splash for this to be the predominant manner of dispersal. We have shown, by flash-photography, that upward splash is entirely adequate for this purpose. In one particular instance, when the leaf bearing the pustule was protected from drops falling from above, precipitation amounting to 0.6 in., completely removed all loose spores from a heavily-encrusted pustule by upward splash from neighbouring leaves alone. The concentration of the spore-suspension falling from the tips of leaves during a rain storm often very greatly exceeds that necessary for infection.

Additional evidence in favour of dispersal by water has been provided by Bock ${ }^{10}$ in a study of the development of rust epiphytotics during which the lesions on more than $8,960,000$ leaves were counted and recorded more than 5 rust cycles, or two and a half years. He concluded that his data were completely explicable if water-dispersal were effective, but not if spore movemont were by air.

The long-range dispersal of $H$. vastatrix has been cited by Raynor as evidence favouring dispersal by air, although Butler"1 considered that movement from Africa to Asia was probably by infected plant material. In fact Rayner ${ }^{6}$ has himself given one instance of the introduction of the disease into the New World by this means: fortunately this was detected in time and suppressed. Coffee in South America is still free from the disease - a circumstance inexplicable if long-range disporsal by air were effective.

Full accounts of the work on inoculum-potential and splash-distribution of $H$. vastatrix will appear elsewhere.

\section{F. J. NUTMAN}

F. M. ROBERTg

Coffee Berry Disease Research Unit,

Scott Agricultural Laboratories, P.O. Box 30028, Nairobi.

1 Rayner, R. W., Nature, 191, 725 (1961).

8 Nutman, F. J., Roherts, F, M., and Bock, K. R., Trans, Brib. Mycol. Snc., 48, 509 (1960).

Bock, K. R., Trans. Brit. Mycol. Soc. (in the press).

- Rayner, R. W., Kenya Coffee, 65 (1956).

5 Rayner, R. W., World Crops, 12, 5 (1960).

- Rayner, R, W., World Crops, 12, 6 (1960).

' Harrington, J. B., Gill, G. C., and Warr, V. R., J. Allergy, 80, 357 (1959).

- Burdekin, D. A., Kenya Coffee, 25, 212 (1960).

- Graumann, E., Principles of Plant Infection (Crosby, Lockwood and Son, 1950).

10 Bock, K. R., Trans. Brit. Mycol. Soc. (in the press).

"Butler, E. J., Fungi and Disease in Plants (Thacker, Spink and Co., 1918).

\section{Embedding Large Slices of Plant Tissue for Electron Microscopy}

The most suitable impregnating resins for ultrathin sectioning of plant tissue penetrate very slowly to the centre of large masses of cells. This has rostricted the range of problems which can be investigated. The following simple technique, an adaptation of that suggested by Luft ${ }^{1}$, was evolved to embed and section successfully pieces of plant tissue, both meristematic and vacuolated, up to $1 \mathrm{~mm} .{ }^{3}$.

Shell 'Epikote Resin 812', which is slightly loss viscous than Ciba 'Araldite resin $M$ ' but otherwise possesses all the virtues of the latter, was used exclusively. Luft's method was followed closely, and the most successful balance of hardeners for meristematic tissue was found to be four parts of the methyl nadic anhydride mixture to six parts of the dodecenyl succinic anhydride mixture. Equal parts of the two hardener mixtures are preferred for slightly harder tissue, for example, vacuolated cells of the root tip of broad bean.

The tissue is isolated, fixed and stained in the conventional way. Potassium permanganate, formalde. hyde and osmium tetroxide were all used successfully as fixatives, and no differences in the penetration of the resin were noticed. The tissue is dehydrated through an ascending alcohol series and after the 100 per cent ethanol stage is given two $\frac{1}{2}$-hr. washes in 100 per cent propylene oxide. The blocks of tissue 